\title{
Metastatic vulvo-vaginal choriocarcinoma mimicking a Bartholin cyst and vulvar hematoma-two unusual presentations
}

\author{
Bartolin kistini ve vulvar hematomayı taklit eden metastatik vulvovajinal \\ koryokarsinom-Iki olağandışı olgu sunumu
}

\author{
Sanjoy Kumar Bhattacharyya, Shyama Prasad Saha, Gautam Mukherjee, Jaydeep Samanta \\ Department of Gynecology and Obstetrics, North Bengal Medical College, Darjeeling, West Bengal, India
}

\section{Abstract}

Metastatic choriocarcinoma may present solely as a vulvo-vaginal growth. It may pose initial diagnostic dilemmas and thus treatment delay. Two cases of metastatic choriocarcinoma which presented as vulvo-vaginal swelling are described here. Both the cases were initially misdiagnosed. Later, unresponsiveness to treatment alerted us to the possibility of metastatic choriocarcinoma. Combination chemotherapy was started following diagnosis by serum $\beta$-HCG titer. In spite of initial responsiveness in both cases, one could not be saved due to poor compliance. Suspicion of metastatic choriocarcinoma should be kept in mind while dealing with any recent onset vulvovaginal swelling following a pregnancy. It may initially mislead the clinician due to its apparent benign appearance.

(J Turkish-German Gynecol Assoc 2012; 13: 218-20)

Key words: Choriocarcinoma, metastasis, vulvo-vaginal

Received: 21 September, 2011

Accepted: 29 October, 2011

\section{Introduction}

Choriocarcinoma is a highly vascular tumour of the trophoblast with immense metastatic potential to the lung, liver, brain or vulva. Next to the lung, vulvo-vaginal metastasis comprises $30 \%$ of all metastatic incidences (1).

Metastasis in this region is often misleading in its initial appearance. Sometimes antecedent pregnancy remains uninformative. Recent onset vulvo-vaginal swelling may be the sole clinical presentation (1). This may confuse the clinician. Here we present two cases of vulvo-vaginal metastasis of choriocarcinoma which were misdiagnosed initially. We present these two cases to remind clinicians about its entity, diagnostic difficulties and treatment options.

\section{Case Reports}

\section{Case 1}

Mrs. A.K., 22 years old, attended out patient department (OPD) with a vulvo-vaginal swelling measuring about $7 \times 5$ $\mathrm{cm}^{2}$. She had a history of uncomplicated home delivery two

\section{Ozet}

Metastatik koryokarsinom yalnızca vulvovajinal tümör olarak görülebilir. Bu durum, ilk tanıda çelişkilere ve dolayısıyla tedavide gecikmeye yol açabilir. Bu çalışmada, vulvovajinal tümör şeklinde prezente olan iki metastatik koryokarsinom vakası tanımlanmıştır. Her iki vaka da başlangıçta yanlış tanı aldı. Daha sonra, tedaviye cevap alınamaması bizi metastatik koryokarsinom ihtimaline karşı alarma geçirdi. Hastanın serum $\beta$-HCG değerleri ölçülüp tanısı konduktan sonra kombine kemoterapi uygulanmaya başlandı. İki vakada da başlangıçta tedaviye cevap alınamamasına rağmen, bir tanesi düşük uyumdan dolayı kurtarılamadı. Hamilelik sonrası yakın zamanda vulvovajinal şişme görülmesi durumunda metastatik koryokarsinom şüphesi akılda tutulmalıdır. Bariz benign görünümünden dolayı başlangıçta hekimi yanlış yönlendirebilir. (J Turkish-German Gynecol Assoc 2012; 13: 218-20)

Anahtar kelimeler: Koryokarsinom, metastaz, vulvovajinal

Geliş Tarihi: 21 Eylül 2011

Kabul Tarihi: 29 Ekim 2011

months previously. The swelling was angry looking, bluish red in color along with infected crusts and oozing surfaces (Figure 1). It was tender and firm. Treatment was initiated on the line of an old infected vulvar hematoma with local wound care, antibiotics and blood transfusion. Despite this, the swelling gradually increased in size. A suspicion of choriocarcinoma arose. Serum $\beta$-hCG titer was measured. The value was $1.2 \times 10^{5}$ I.U. $/ \mathrm{mL}$, which confirmed the diagnosis. Combination chemotherapy with MAC (Methotrexate, Actinomycin and Cyclophosphamide) regimen was started. There was 50\% shrinkage of the mass following the first course. Serum $\beta$-hCG titer had been reduced to 60.200 I.U./mL. She left the hospital after the first course despite repeated counseling and did not come back for follow up. She was admitted three weeks later with massive vaginal bleeding and a very poor general condition. She developed convulsions and died on the next day in spite of aggressive supportive measures.

\section{Case 2}

Mrs. P.M. a 25 year-old primipara attended OPD with a swelling over the left vulva measuring $4 \times 3 \mathrm{~cm}^{2}$ which she 
had noticed two months previously. She had a history of full term vaginal delivery three and half years earlier. The swelling was tense, tender, cystic and infected looking. It was provisionally diagnosed as an infected Bartholin cyst and surgical intervention was planned. We encountered unexpected, profuse, uncontrollable hemorrhage during the procedure. However, the bleeding was managed at that time by deep mattress sutures but it recurred after two weeks. On repeated enquiry, she then revealed a history of Medical termination of pregnancy (MTP) at 8 weeks gestation performed surgically four months earlier. A suspicion of choriocarcinoma arose and her serum $\beta$-hCG titer was estimated. It had a value of $1.5 \times 10^{5} \mathrm{I} . \mathrm{U} . / \mathrm{ml}$. Other relevant investigations were carried out, however they revealed no other distant metastasis except a sonological finding of a bulky uterus. The first course of chemotherapy was started with EMACO (Etoposide, Methotrexate, Actinomycin, Cyclophosphamide and Oncovin) regimen. The mass shrunk in size but vaginal bleeding was still continuing from the internal os. We planned a laparotomy due to persistence of bleeding. Laparotomy findings revealed a bulky uterus of approximate 10 weeks size along with gross adhesions to surrounding structures. Careful bilateral internal iliac artery ligation was performed. A second course of chemotherapy was started at a later date. Her $\beta$-hCG titer declined gradually, with improvement of general condition. She received 6 courses of combination chemotherapy and recovered completely. She is now on follow up and doing well.

\section{Discussion}

These two similar cases are presented because of their initial diagnostic dilemmas and subsequent management protocol. Vulvo-vaginal metastasis of trophoblastic tumour may occur even after first trimester loss. Gary L Goldberg in omit similar study showed that, out of five cases of vulvo-vaginal metastasis, two developed following spontaneous abortion (2).

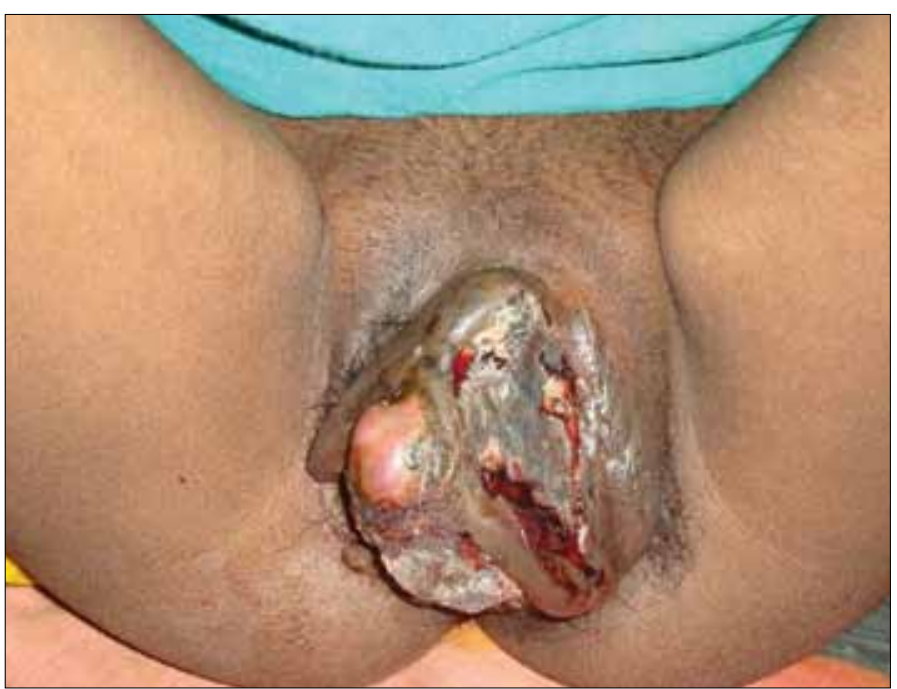

Figure 1. Metastatic vulvovaginal choriocarcinoma mimicking an old infected vulvar hematoma
In present study, the first case was treated conservatively for a week as an old infected vulvar hematoma without any improvement. Initially its malignant nature was not considered. Perhaps, with an earlier appropriate intervention, we might have gained the confidence of her relatives and could have saved her life.

The second case was erroneously diagnosed as infected Bartholin cyst which bled profusely during surgical intervention. As these sites which the tumor itself are hypervascular in nature, any local surgical intervention may precipitate life threatening hemorrhage. Here the question arises whether to perform biopsy or is it needed at all for confirmation of the diagnosis. Essentially, diagnosis of metastatic choriocarcinoma is based on history, clinical presentation and allied elevated serum $\beta$ - HCG titer. Biopsy from the local metastatic sites is not mandatory for the diagnosis. Song et al in their study also supported this view (1).

Chemotherapy is the treatment of choice with a favorable prognosis (3). Regarding prognostic scoring, vulvo-vaginal metastasis should be considered as a poor prognostic factor. Different studies in this context thus directly recommended combination chemotherapy as their first choice $(2,3)$. The problem lies in the interim period regarding control of bleeding from these hypervascular sites. Options like intravaginal packing; hemostatic, deep, figure-of-eight mattress suturing or more extensive surgical interventions like hysterectomy along with ligation of feeding vessels had been advocated by different investigators $(1,2)$. The method of intravaginal packing and its subsequent removal needs special mention. Packing should be initiated cautiously with soaked roller gauze under direct vision after covering the oozing nodules with separate soaked gauze-pieces. Packing may be offered also following hemostatic suturing. Abrasions, during changing of pack, may incite fresh bleeding. So, placing the fingers first between the packing and covering gauze and subsequently proceeding to pack-removal might prevent such a complication.

Even both procedures might not be able to control bleeding, especially where there is pelvic involvement, as in the second case, or in cases of large, friable metastatic foci. More extensive procedures such as abdominal hysterectomy with simultaneous ligation of ovarian and internal iliac artery may be needed in these circumstances. However, radiological embolisation of feeding vessels can be an effective alternative in these circumstances and if opted, can avoid the need for complicated surgical procedures $(1,2)$.

Follow-up should be carried out as usual with the level of serum $\beta$-hCG titer along with clinical correlation. Prognosis is usually good provided interim bleeding episodes are tackled efficiently and long term follow up is accepted.

\section{Conclusion}

While dealing with a case of vulvo-vaginal swelling with a history of antecedent pregnancy, one should always remember the remote possibility of a metastatic choriocarcinoma and investigate accordingly. Prompt diagnosis and early treatment with combination chemotherapy may thus save many lives by keeping its probability in mind. 


\section{Conflict of interest}

No conflict of interest was declared by the authors.

\section{References}

1. Yingna S, Yang X, Xiuyu Y, Hongzhao S. Clinical characteristics and treatment of gestational trophoblastic tumor with vaginal metastasis. Gynecol Oncol 2002; 84: 416-9. [CrossRef]
2. Goldberg GL, Yon DA, Bloch B, Levin W. Gestational trophoblastic disease: the significance of vaginal metastases. Gynecol Oncol 1986; 24: 155-61. [CrossRef]

3. Ghaemmaghami F, Behroozi S, Mousavi A, Ashrafgangooei T, Gilani MM, Behtash N, et al. Assessment of the response to chemotherapy in gestational trophoblastic neoplasia with vaginal metastases. Arch Gynecol Obstet 2008; 278: 315-8. [CrossRef]

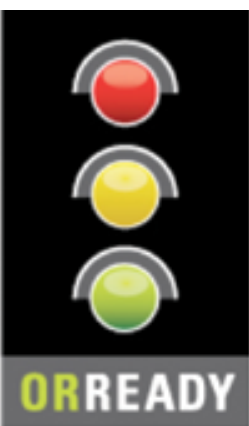

We are ORReady and support operating room safety to improve patient outcome.
ORReady is a worldwide, multi-Specialty initiative to encourage steps that are known to improve surgical outcomes and save lives.

If the suggested guidelines, which include Check Lists, Time Outs and Warm Ups are followed routinely, we estimate that Six Million patients around the world could have better outcomes.

Find out how your department and hospital can be ORReady and improve outcomes at http://www.sls.org/outcome 